Check for updates

Montreal

Cite this as: $B M J 2020 ; 370: \mathrm{m} 2720$ http://dx.doi.org/10.1136/bmj.m2720 Published: 07 July 2020

\section{Covid-19: Airborne transmission is being underestimated, warn experts}

\section{Owen Dyer}

Microscopic respiratory droplets generated by talking and breathing can hover in the air for minutes or hours and drift many metres horizontally before infecting people, argue 239 experts from 32 countries, in a commentary published in Clinical Infectious Diseases. ${ }^{1}$

"We appeal to the medical community and to the relevant national and international bodies to recognise the potential for airborne spread of covid-19," wrote the scientists, who include physicians, epidemiologists, and experts in environmental health and building design.

"Studies by the signatories and other scientists have demonstrated beyond any reasonable doubt" that airborne droplets can pose a risk beyond $2 \mathrm{~m}$ from an infected person, the authors argued. They cited the case of a Chinese restaurant where video captured an evening in which the virus spread from one table to others with no evidence of contact, direct or indirect, between the diners. ${ }^{2}$

"By 'airborne' we mean that the virus can be transmitted by inhalation of microscopic droplets generated from breathing, talking, singing, and not just from coughing and sneezing," said Don Milton, professor of environmental health at the University of Maryland and one of the commentary's authors. "This does not mean that the virus can spread as easily over long distances as do measles or tuberculosis. Most transmission happens in closed, indoor spaces where there is poor ventilation and crowding, and people are close together and talking loudly or singing without masks."

Researchers have been unable to grow coronavirus from aerosols in patients' hospital rooms, but these settings were unusually well ventilated, the commentary's authors contend.

Although the commentary does not single out any agencies, several of the signatories have lobbied the World Health Organization to recommend greater precautions against airborne transmission. WHO recommendations have prioritised hand washing and focused on the risk from coughed or sneezed droplets and infected surfaces.

The New York Times spoke to several anonymous WHO consultants who praised the agency's overall effort but said that its infection prevention and control committee was bound by a rigid view of scientific evidence, was slow and risk averse in updating its guidance, and allowed a few conservative voices to drown out dissent.

The WHO and the US Centers for Disease Control and Prevention recommended protection against aerosolised virus only during invasive medical procedures such as intubation. The commentary's signatories argue that agencies should be guided by the precautionary principle and should now recommend simple steps to counter potentially widespread aerosol transmission.

Some members of WHO's infection prevention and control committee have pointed to the opportunity cost if poorer countries are forced to redesign ventilation systems to counter a threat that is still not fully proved. Hospitals that recirculated air might need to install special filters and decontaminating ultraviolet bulbs, diverting resources from treatment.

But just opening windows could be the most effective measure, said Lidia Morawska, a professor in atmospheric sciences at the Queensland University of Technology and the organiser of the commentary.

"Opening windows to increase ventilation is the first thing to do," she told The BMJ. "What's most important is the recognition that we need good ventilation to remove the virus from the air."

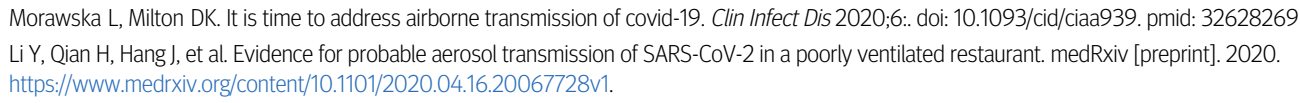

This article is made freely available for use in accordance with BMJ's website terms and conditions for the duration of the covid-19 pandemic or until otherwise determined by BMJ. You may use, download and print the article for any lawful, non-commercial purpose (including text and data mining) provided that all copyright notices and trade marks are retained. 